\title{
У Koronaepidemian ja sen rajaamistoimien vaikutukset elintapoihin ja arkielämään koulutusryhmittäin
}

Koronaepidemia ja sen rajaamistoimet ovat vaikuttaneet monin tavoin väestön terveyteen ja hyvinvointiin, ja monien haitallisten vaikutusten on arveltu kasaantuneen heikommassa sosioekonomisessa asemassa oleviin väestöryhmiin. Tutkimustietoa aiheesta on kuitenkin niukasti. Tämän tutkimuksen tavoitteena on tarkastella koronaepidemian vaikutuksia elintapoihin ja arkielämään eri koulutusryhmissä.

Tutkimus perustuu satunnaisesti valittujen 30-69-vuotiaiden henkilöiden antamiin vastauksiin THL:n kolmessa aikuisväestöä edustavassa väestötutkimuksessa: Koronaepidemian serologinen väestötutkimus $(n=3772)$, FinSote 2020 -tutkimus $(n=10847)$ ja FinTerveys 2017 -seurantatutkimus $(n=3696)$, joiden tiedonkeruu on toteutettu aikavälillä huhtikuu 2020 ja maaliskuu 2021.

Tulosten perusteella koronaepidemian ja sen rajaamistoimien vaikutukset elintapoihin ja arkielämään ovat moninaisia, mutta erityisesti elintapojen osalta pitkälti samanlaisia eri koulutusryhmissä. Työmatkaliikunta väheni erityisesti ylimpään koulutusryhmään kuuluvilla, mitä selittänee etätyön yleistyminen. Ylimpään koulutusryhmään kuuluvat raportoivat myös sosiaalisissa suhteissa tapahtuneita kielteisiä muutoksia alimpaa koulutusryhmää yleisemmin. Taloudelliset haasteet olivat sen sijaan yleisempiä alimmassa koulutusryhmässä.

Terveyden ja hyvinvoinnin kannalta epäsuotuisat muutokset arkielämässä ja elintavoissa saattavat pitkällä aikavälillä heïjastua lisääntyneenä sairastavuutena ja kansanterveyden yleisenä heikkenemisenä. On myös mahdollista, että epidemia pitkittyessään entisestään kärjistää sosioekonomisia terveys- ja hyvinvointieroja, mikäli tuloerot kasvavat ja työelämämuutokset ovat eri suuntaisia eri väestöryhmissä. Jotta mahdolliset terveyden ja hyvinvoinnin kannalta epäsuotuisat kehityskulut voidaan havaita ajoissa ja tunnistaa ne väestöryhmät, joissa riski epäsuotuisalle kehitykselle on lisääntynyt, ajankohtainen, luotettava tieto epidemian vaikutuksista on välttämätöntä.

ASIASANAT: COVID-1 9 epidemia, sosioekonominen asema, terveyserot, koulutusryhmät

PEPPI HAARIO, PÄIVIKKI KOPONEN, SUVI PARIKKA, TOMMI HÄRKÄNEN, TUIJA MARTELIN, SEPPO KOSKINEN, ANNAMARI LUNDQVIST 


\section{YDINASIAT}

- Koronaepidemian ja sen rajaamistoimien vaikutukset elintapoihin olivat moninaisia, mutta pitkälti samanlaisia eri koulutusryhmissä.

- Työmatkaliikunta väheni erityisesti ylimmässä koulutusryhmässä, mitä selittänee etätyön yleistyminen.

- Ylimpään koulutusryhmään kuuluvat raportoivat myös yleisemmin sosiaalisissa suhteissa tapahtuneita kielteisiä muutoksia.

- Taloudelliset haasteet ovat yleisempiä alimmassa koulutusryhmässä.

- On tärkeää arvioida epidemian pitkäaikaisia vaikutuksia sosioekonomisiin terveys- ja hyvinvointieroihin ja tunnistaa tekijät, jotka myötävaikuttavat epäsuotuisiin muutoksiin.

\section{JOHDANTO}

Koronaepidemian ensimmäinen aalto levisi nopeasti Suomessa keväällä 2020 ja vaikutti merkittävästi yhteiskuntaamme. Hallitus julisti poikkeustilan 16.3.-16.6.2020 ja se vaikutti ennennäkemättömällä tavalla monien suomalaisten arkeen. Koronaviruksen leviämisen estämiseksi otettiin käyttöön erilaisia kansallisia rajoitustoimenpiteitä esim. koulut ja oppilaitokset sekä monet julkiset tilat ja ravitsemisliikkeet suljettiin ja yli kymmenen hengen kokoontumiset kiellettiin. Epidemiatilanteen rauhoittuessa rajoituksia purettiin kesällä 2020, mutta kiristettiin jälleen syksyllä ja erityisesti talvella tautitapausten määrän lisääntyessä.

Jo koronaepidemian alkuvaiheista lähtien on ollut nähtävissä, että epidemialla ja sen rajaamistoimilla on laaja-alaisia ja kauaskantoisia vaikutuksia yhteiskuntaan. Vaikutukset väestön terveyteen ja hyvinvointiin ulottuvat selvästi infektiotautia laajemmalle ja muun muassa ammatti, elin- ja työympäristö, toimeentulo sekä aiempi terveydentila saattavat merkittävästi muovata näitä vaikutuksia. Aiemman kirjallisuuden perusteella on arvioitu, että terveyden ja hyvinvoinnin kannalta epäsuotuisat vaikutukset saattavat kasautua heikommassa sosioekonomisessa asemassa oleviin väestöryhmiin (1-2) ja siten epidemia saattaa lisätä sosioekonomisia terveys- ja hyvinvointieroja entisestään. Luotettavaa tietoa tästä on kuitenkin niukasti.

Tämän tutkimuksen tarkoituksena on arvioida, millaisia vaikutuksia koronaepidemialla ja sen rajaamistoimilla on ollut elintapoihin ja arkielämään ja tarkastella ovatko vaikutukset olleet samansuuntaisia eri koulutusryhmissä. Tulokset ovat ensiarvoisen tärkeitä, jotta tuki- ja ehkäisytoimet voidaan kohdistaa niihin väestöryhmiin, joissa on suurin riski terveyden ja hyvinvoinnin kannalta epäsuotuisille muutoksille.

\section{MENETELMÄT}

Tutkimus perustuu kolmeen Terveyden ja hyvinvoinnin laitoksen toteuttamaan aikuisväestöä edustavaan väestötutkimukseen: Koronaepidemian serologinen väestötutkimus, FinSote 2020 -tutkimus ja FinTerveys 2017 -seurantatutkimus. Tarkastelu rajattiin kaikissa aineistossa 30-69 -vuotiaisiin. Nuorimmilla koulutus on usein kesken, jolloin tässä tutkimuksessa käytetty koulutusvuosiin perustuva tarkastelu ei tuota heistä luotettavaa kuvaa. Lisäksi 18-29-vuotiaita kutsuttiin ja osallistui em. tiedonkeruisiin varsin vähän.

Koronaepidemian serologisessa väestötutkimuksessa tutkitaan koronaviruksen leviämistä Suomessa selvittämällä ajantasaisesti, kuinka suurelta osuudelta väestöstä löytyy verestä koronaviruksen vasta-aineita merkkinä viruksen kohtaamisesta. Tutkimus käynnistyi huhtikuun alussa 2020, ja siihen on kutsuttu alkuvaiheessa viikoittain ja myöhemmin joka toinen viikko uusi, satunnaisesti valittu otos 18-69-vuotiaita aikuisia. Verinäytteen lisäksi tutkittavia pyydettiin täyttämään sähköinen kysely, jolla kartoitetaan koronaepidemian vaikutuksia väestön terveyteen ja hyvinvointiin. Tässä tutkimuksessa hyödynnetään 30-69-vuotiaiden antamia vastauksia, jotka on saatu aikavälillä 28.4.2020-3.3.2021 ( $n=3772$, osallistumisaktiivisuus $39 \%$ ).

FinSote 2020 -tutkimus on kansallinen terveys-, hyvinvointi- ja palvelututkimus, jonka avulla seurataan terveydessä ja hyvinvoinnissa tapahtuvia muutoksia eri väestöryhmissä ja alueittain. FinSote 2020 -tutkimuksen tiedonkeruu toteutettiin syyskuun 2020 ja helmikuun 2021 välisenä aikana. Koronakysymykset sisältävä kyselylomake lähetettiin 48400 satunnaisesti valitulle henkilölle, joka edustaa 20 vuotta täyttänyttä Suomessa asuvaa väestöä. Tässä tutkimuksessa hyödynnetään aineistoa, joka käsittää 10847 30-69-vuotiaista (osallistumisaktiivisuus $42 \%$ ).

FinTerveys-tutkimus tuottaa tietoa Suomessa asuvien aikuisten terveydestä ja hyvinvoinnista 
Taulukko 1. Aineistojen kuvailu.

\begin{tabular}{lrrrrrr}
\hline & $\begin{array}{l}\text { Koronaepidemian } \\
\text { serologinen } \\
\text { väestötutkimus }\end{array}$ & $\begin{array}{l}\text { FinTerveys 2017- } \\
\text { seurantatutkimus }\end{array}$ & FinSote 2020-tutkimus \\
\hline Taustamuuttujat & $\mathrm{n}$ & \multicolumn{1}{c}{$\%$} & $\mathrm{n}$ & $\%$ & $\mathrm{n}$ & $\%$ \\
\hline Sukupuoli & & & & & & \\
Miehet & 1499 & 40 & 1716 & 51 & 4893 & 50 \\
Naiset & 2273 & 60 & 1980 & 49 & 5954 & 50 \\
Yhteensä & 3772 & 100 & 3696 & 100 & 10847 & 100 \\
\hline Keski-ikä (vuotta) & 51 & & 50 & & 50 & \\
30-49-vuotiaat & 1728 & 46 & 1495 & 40 & 3563 & 48 \\
$50-69-v u o t i a a t$ & 2044 & 54 & 2210 & 60 & 7284 & 52 \\
\hline Koulutus* & & & & & & \\
Alin koulutus & 793 & 21 & 996 & 32 & 3978 & 41 \\
Keskitasoinen koulutus & 1132 & 31 & 1080 & 32 & 3670 & 33 \\
Ylin koulutus & 1790 & 48 & 1174 & 36 & 2983 & 26 \\
\hline Pääasiallinen toiminta & & & & & & \\
Työssä (osa-aikatyössä, kokopäivätyössä) & 2495 & 67 & 2322 & 69 & 5831 & 61 \\
Työtön (työtön, lomautettu) & 340 & 9 & 209 & 6 & 692 & 8 \\
Eläkkeellä & 584 & 16 & 885 & 18 & 2642 & 15 \\
Muut & 321 & 10 & 223 & 7 & 1449 & 16 \\
\hline
\end{tabular}

*Koulutus= koulutusvuosista ikäryhmittäin ja sukupuolittain lasketut tertiilit, Serologisen väestötutkimuksen osalta tertiilit perustuvat FinSote-aineistoon.

ja niihin vaikuttavista tekijöistä. FinTerveys 2017 -tutkimukseen valittiin satunnaisotannalla väestörekisteristä 10305 yli 18-vuotiasta Suomessa asuvaa henkilöä, jotka kutsuttiin vuonna 2017 laajaan terveystarkastukseen. Seurantatiedonkeruu toteutettiin aikavälillä lokakuu 2020- tammikuu 2021 ja siihen kutsuttiin kaikki alkuperäiseen FinTerveys 2017 -otokseen kuuluneet, jotka olivat elossa, asuivat Suomessa eivätkä olleet kieltäytyneet myöhemmistä yhteydenotoista ( $\mathrm{n}=9580)$. Tutkittavilla oli mahdollisuus osallistua tutkimukseen vastaamalla joko sähköiseen tai paperiseen kyselyyn. Mikäli tutkittava ei halunnut tai pystynyt täyttämään kyselyä, hänelle tarjottiin mahdollisuutta osallistua puhelinhaastatteluun. 30-69-vuotiaista tutkimukseen kutsutuista siihen osallistui 3969 (osallistumisaktiivisuus $54 \%$ ).

Sosioekonomisen aseman kuvaamiseen käytettiin koulutusta, jota kartoitettiin kysymyksellä: "Kuinka monta vuotta olet yhteensä käynyt koulua ja opiskellut päätoimisesti? Kansa- ja peruskoulu sekä näiden jälkeiset opinnot lasketaan mukaan”. FinTerveys-aineistossa ao. kysymys sisältyi vuoden 2017 tiedonkeruuseen. Kolmiluokkainen koulutusmuuttuja muodostettiin käyttämällä luokkarajoina ikäryhmittäin ja sukupuo- littain laskettuja koulutusryhmätertiilejä, jotka muodostettiin aineistokohtaisesti FinSote- ja FinTerveys-tutkimuksissa. Serologisen väestötutkimuksen osalta tertiilit perustuivat FinSote-aineiston rajoihin.

Pääasiallista toimintaa kysyttiin kaikissa tutkimuksissa samalla kysymyksellä, mutta vastausvaihtoehdot vaihtelivat. Analyyseja varten muuttuja luokiteltiin samalla tavalla: 1) työssä (osaaikatyössä, kokopäivätyössä), 2) työtön (työtön, lomautettu), 3) eläkkeellä iän perusteella ja 4) muut.

Koronaepidemian vaikutuksia elintapoihin kartoitettiin tiedustelemalla ovatko epidemia tai sen rajaamistoimet vaikuttaneet liikuntaan, tupakointiin, alkoholinkäyttöön ja ravitsemustottumuksiin (ks. taulukko 2). Vastausvaihtoehdot olivat: 1) ei vaikutusta, 2) kyllä, vähentynyt, 3) kyllä, lisääntynyt, 4) ei koske minua. Vaihtoehdon 4 valinneet poistettiin analyyseista. Vastaavalla tavalla kartoitettiin epidemian vaikutuksia sosiaalisiin suhteisiin ja muuhun arkielämään (esim. perheen kanssa vietetty aika sekä yksinäisyyden ja läheisyyden tunne, ks. taulukko 3). Kaikissa kolmessa aineistossa on käytetty pääosin samanlaisia kysymyssarjoja. 


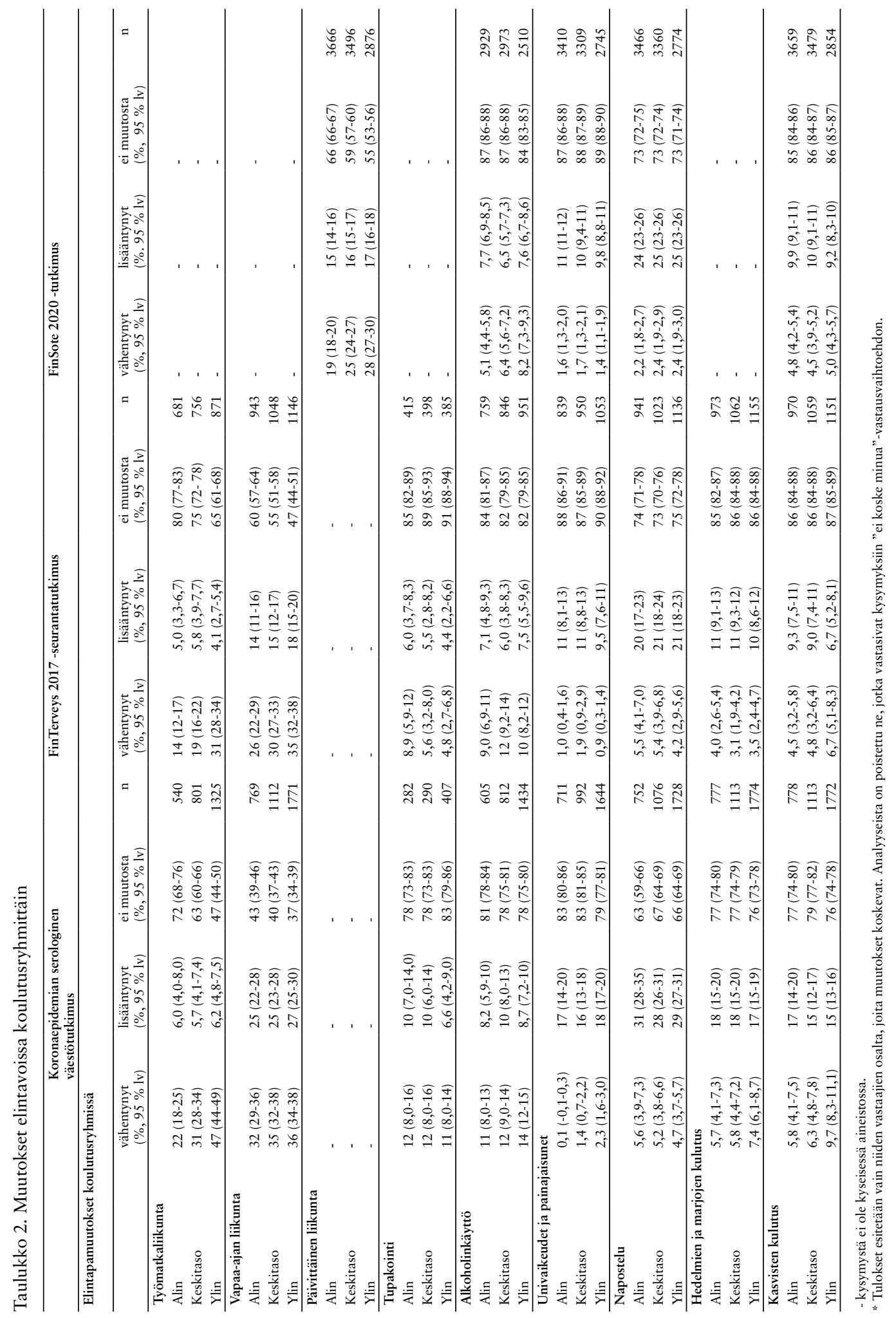




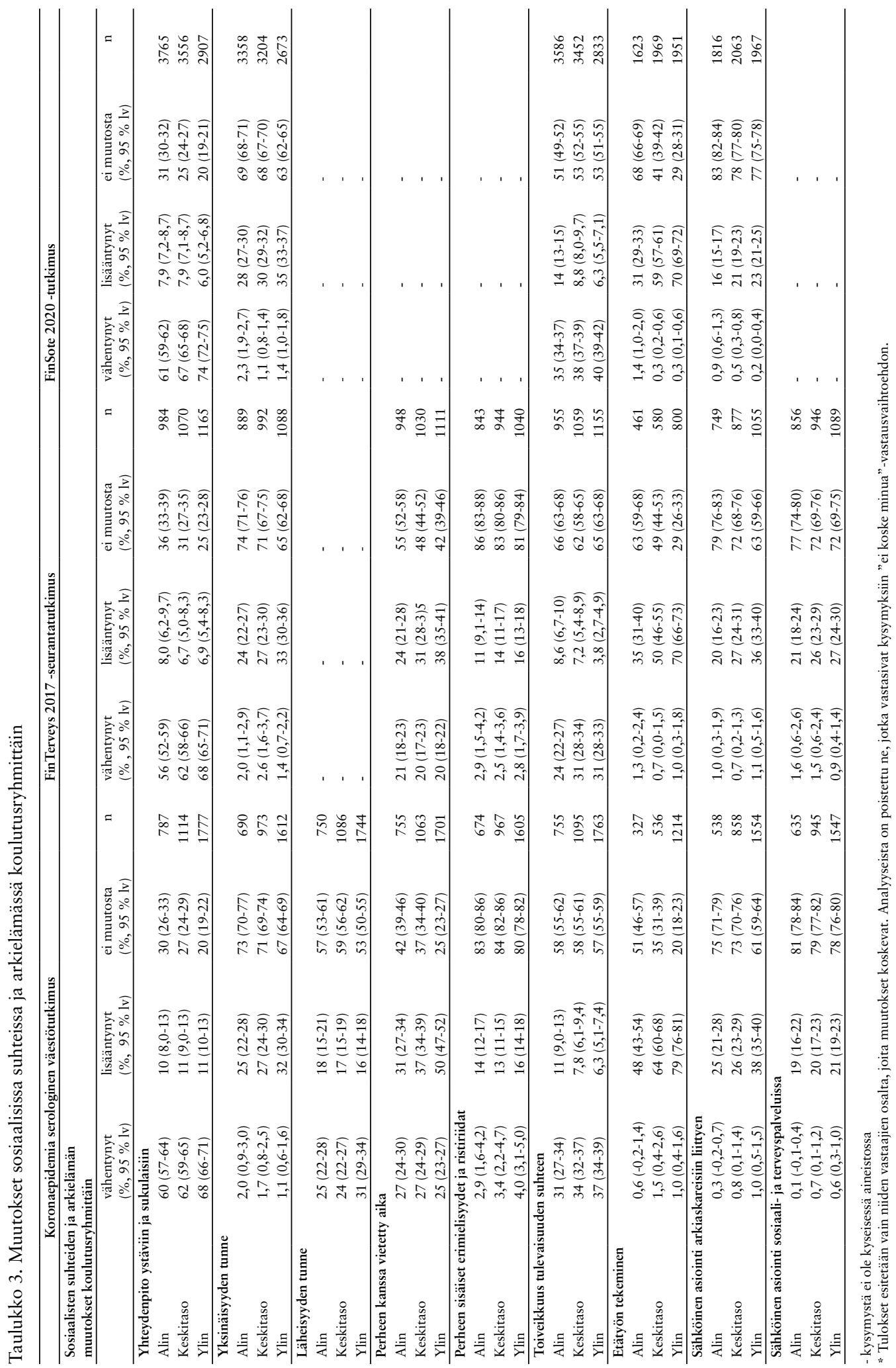


Koronaepidemian aiheuttamaa taloudellisen toimeentulon muutosta arvioitiin kysymyksellä: "Onko koronaepidemia heikentänyt taloudellista tilannettasi?" Vastausvaihtoehtoina olivat: 1) erittäin paljon, 2) melko paljon, 3) jonkin verran, 4) vähän, 5) ei lainkaan. Vaihtoehdot 1, 2 ja 3 luokiteltiin heikentyneeksi taloudelliseksi tilanteeksi.

\section{TILASTOLLISET ANALYYSIT}

Koulutusryhmien eroja verrattiin tarkastelemalla vakioimattomia keskiarvoja ja niiden luottamusvälejä. Analyysit perustuivat asetelmaperusteisiin menetelmiin, jolloin voidaan huomioida kadon vaikutukset käyttämällä painokertoimia sekä otanta-asetelman vaikutukset varianssiestimaatteihin käyttämällä linearisointia (3).

Koska vähemmän koulutettujen osallistumisaktiivisuus on selvästi keskimääräistä alhaisempi, on kadon vaikutuksia tuloksiin pyritty minimoimaan käyttämällä analyyseissa rekisteritietoihin perustuvaa ikää, sukupuolta, siviilisäätyä, koulutusastetta, kieltä ja tutkimusaluetta, ja niiden mukaan muodostettuja painokertoimia (3-5), jotka määritettiin erikseen kuhunkin kolmeen aineistoon.

\section{TULOKSET}

Tutkimus perustuu 30-69-vuotiaiden vastauksiin THL:n kolmessa aikuisväestöä edustavassa väestötutkimuksessa: Koronaepidemian serologinen väestötutkimus (n=3772), FinSote 2020 -tutkimus $(n=10847)$ ja FinTerveys 2017 -seurantatutkimus $(\mathrm{n}=3696)$, joiden kyselytiedonkeruu on toteutettu aikavälillä huhtikuu 2020 ja maaliskuu 2021. Tutkimuksiin osallistuneista naisia oli $57 \%$. Hieman suurempi osuus Koronaepidemian serologiseen väestötutkimukseen $(67 \%)$ ja FinTerveysseurantatutkimukseen (69\%) osallistuneista oli työssäkäyviä verrattuna FinSote 2020-tutkimukseen osallistuneisiin (61\%). Työttömiä eri aineistoissa oli lähes saman verran (6-9\%).

\section{MUUTOKSET ELINTAVOISSA}

Ylimmässä koulutusryhmässä olevat raportoivat selvästi useammin vähentäneensä työmatkaliikuntaa alimpaan verrattuna (Taulukko 2). Työmatkaliikuntaa vähentäneiden osuus oli yli kaksinkertainen ylimmässä koulutusryhmässä alimpaan verrattuna sekä Serologisessa väestötutkimuksessa (47\% vs. $22 \%$ ) että FinTerveys 2017 -seurantatutkimuksessa (31 \% vs. $14 \%$ ). Myös va- paa-ajan liikuntaa vähentäneiden osuus oli FinTerveys 2017 -seurantatutkimusaineistossa suurempi ylimmässä kuin alimmassa koulutusryhmässä (35\% vs. $26 \%$ ), mutta Serologisen väestötutkimuksen aineistossa merkitsevää eroa ei ollut. Toisaalta FinSote 2020-tutkimuksessa, jossa kartoitettiin päivittäisessä liikunnassa kokonaisuudessaan tapahtuneita muutoksia, sekä liikunnan lisääminen että vähentäminen oli yleisempää ylimmässä koulutusryhmässä alimpaan verrattuna (17\% vs. $15 \%$ ja $28 \%$ vs. $19 \%$ ).

Sen sijaan tupakoinnin muutoksissa ei havaittu eroja koulutusryhmien välillä. FinSote 2020-tutkimuksessa havaittiin pieniä eroja alkoholinkäytön vähenemisessä ylimmän ja muiden koulutusryhmien välillä. Ylimpään koulutusryhmään kuuluvat raportoivat hieman muita koulutusryhmiä useammin alkoholinkäytön vähentyneen ( $8 \%$ vs. 5-6\%). Vastaajista noin joka kymmenes, Serologisen väestötutkimuksen aineistossa jopa joka kuudes, kertoi univaikeuksien ja painajaisunien lisääntyneen, mutta koulutusryhmien välillä ei havaittu eroja.

Koronaepidemian ja sen rajaamistoimien vaikutuksia ravitsemustottumuksiin kartoitettiin kysymällä kasvisten sekä hedelmien ja marjojen kulutuksessa sekä napostelussa tapahtuneita muutoksia. Vastanneista 20-31 prosenttia oli lisännyt napostelua, noin 10-18 prosenttia kertoi lisänneensä hedelmien ja marjojen kulutusta ja kasvisten kulutusta lisänneitä oli 7-17 prosenttia. Koulutusryhmien välillä ei havaittu eroja.

\section{MUUTOKSET SOSIAALISISSA SUHTEISSA JA ARKIELÄMÄSSÄ}

Ylimmässä koulutusryhmässä olevat kertoivat yleisemmin koronaepidemian ja sen rajaamistoimien vaikuttaneen sosiaalisiin suhteisiinsa kuin alimpaan koulutusryhmään kuuluvat (Taulukko 3). Ylimmässä koulutusryhmässä olevista joka kolmas koki yksinäisyyden tunteen lisääntyneen, kun alimmassa koulutusryhmässä näin tunsi joka neljäs. Vastaavasti ylimmässä koulutusryhmässä olevat kokivat useammin toiveikkuuden tulevaisuuden suhteen ja läheisyyden tunteen muihin ihmisiin vähentyneen. Alimmassa koulutusryhmässä olevat raportoivat hieman ylempää koulutusryhmää useammin lisääntyneestä toiveikkuudesta tulevaisuuden suhteen. Ylimmässä koulutusryhmässä olevista suurempi osuus (68-74\% aineistosta riippuen) kuin alimmassa koulutusryhmässä olevista (56-61\%) kertoi myös yh- 
Taulukko 4. Muutokset taloudellisessa tilanteessa koulutusryhmittäin

\begin{tabular}{|c|c|c|c|c|c|c|}
\hline \multirow[b]{2}{*}{$\begin{array}{l}\text { Muutos taloudellisessa } \\
\text { tilanteessa }\end{array}$} & \multicolumn{2}{|c|}{$\begin{array}{l}\text { Koronaepidemian } \\
\text { serologinen väestötutkimus }\end{array}$} & \multicolumn{2}{|c|}{$\begin{array}{l}\text { FinTerveys } 2017 \text {-seuranta- } \\
\text { tutkimus }\end{array}$} & \multicolumn{2}{|c|}{ FinSote 2020 -tutkimus } \\
\hline & $\begin{array}{l}\text { heikentynyt } \\
(\%, 95 \% \mathrm{lv})\end{array}$ & $\mathrm{n}$ & $\begin{array}{l}\text { heikentynyt } \\
(\%, 95 \% \mathrm{lv})\end{array}$ & $\mathrm{n}$ & $\begin{array}{l}\text { heikentynyt } \\
(\%, 95 \% \mathrm{lv})\end{array}$ & $\mathrm{n}$ \\
\hline Alin & $29(25-32)$ & 791 & $36(32-39)$ & 996 & $27(26-28)$ & 3876 \\
\hline Keskitaso & $23(21-26)$ & 1130 & $33(30-37)$ & 1080 & $22(21-23)$ & 3610 \\
\hline Ylin & $18(16-20)$ & 1783 & $27(24-29)$ & 1174 & $19(18-20)$ & 2931 \\
\hline
\end{tabular}

* Tulokset esitetään vain niiden vastaajien osalta, joita muutokset koskevat. Analyyseista on poistettu ne, jotka vastasivat kysymyksiin "ei koske minua"-vastausvaihtoehdon.

teydenpidon sukulaisiin ja ystäviin vähentyneen. Toisaalta ylimmässä koulutusryhmässä olevat kokivat alimmassa koulutusryhmässä olevista useammin, että perheen kanssa vietetty aika on lisääntynyt (38-50 \% vs. 24-31\%).

Ylimmässä koulutusryhmässä olevat raportoivat etätyön lisääntymistä alimpaa koulutusryhmää useammin (70-79 \% vs. 31-48 \% aineistosta riippuen, taulukko 3). Myös sähköinen asiointi arkiaskareissa, kuten ruokaostosten tekeminen netissä, yleistyi ylimmässä koulutusryhmässä enemmän. Sen sijaan koulutusryhmien välillä ei havaittu eroja, kun tarkasteltiin sähköisen asioinnin lisääntymistä sosiaali- ja terveyspalveluissa.

Kaikkien aineistojen mukaan alimmassa koulutusryhmässä olevat raportoivat ylempää koulutusryhmää useammin, että koronaepidemia on heikentänyt taloudellista tilannetta $(27 \%$ $36 \%$ vs. $18 \%-27 \%$ ) (Taulukko 4.).

\section{POHDINTA}

Tämä tutkimus osoittaa, että koronaepidemia ja sen rajaamistoimet ovat vaikuttaneet monin tavoin ihmisten arkeen. Vaikka vaikutukset ovat pitkälti samanlaisia eri koulutusryhmissä, on havaittavissa myös eroavaisuuksia, joilla saattaa olla merkittäviä ja kauaskantoisia seurauksia. Työmatkaliikunta on vähentynyt erityisesti ylimmässä koulutusryhmässä, mitä selittänee etätyön yleistyminen. Ylimmässä koulutusryhmässä olevat raportoivat alimpaa koulutusryhmää yleisemmin myös kielteisiä muutoksia sosiaalisissa suhteissa ja tulevaisuuden toiveikkuuden vähentymistä. Sen sijaan taloudelliset haasteet ovat yleisempiä alimmassa koulutusryhmässä.

Koronaepidemia on nostanut esiin väestön moninaisuuden ja korostanut kysymystä eriarvoisuudesta. Aiempi tutkimustieto virusepidemioiden ja niiden rajaamistoimien heijastevaikutuk- sista on kuitenkin varsin vähäistä, eikä luotettavaa tietoa vaikutuksista sosioekonomisiin terveys- ja hyvinvointieroihin ole. Kriisin on pelätty osuvan voimakkaimmin jo ennestään heikommassa asemassa oleviin ja vahvistavan siten olemassa olevia jakolinjoja ja jopa synnyttävän uusia. Tämän tutkimuksen tulokset vahvistavat näitä käsityksiä erityisesti, kun tarkastellaan epidemian vaikutuksia taloudelliseen toimeentuloon: alimmassa koulutusryhmässä olevat ihmiset raportoivat ylimmässä koulutusryhmissä olevia selvästi useammin taloudellisen toimeentulon heikkenemistä. Vaikka Suomi on selvinnyt taloudellisessa mielessä koronaepidemiasta suhteellisen hyvin moniin muihin Euroopan maihin verrattuna, taloudelliset ongelmat ja huolet toimeentulon riittävyydestä ovat yleisiä. Työttömyys on lisääntynyt etenkin matalapalkkaisilla aloilla (6) ja taloudellisista ongelmista kertoo myös se, että perustoimeentulotuen tarve on kasvanut.

Sen sijaan epidemian ja sen rajaamistoimien vaikutukset väestön elintapoihin ja sosioekonomisiin elintapaeroihin näyttäisivät olevan pelättyä vähäisempiä. Tupakoinnissa ei näyttäisi tapahtuneen merkittäviä muutoksia epidemian myötä ja alkoholinkulutuksessakin koulutusryhmien väliset erot olivat pieniä. Sen sijaan univaikeuksista ja painajaisunista kärsivien osuus on selvästi lisääntynyt, mutta lisääntyminen on yhtä yleistä ylimmässä kuin alimmassa koulutusryhmässä. Myöskään ravitsemuskäyttäytymisessä ei havaittu selviä koulutusryhmittäisiä eroja, vaikka lisääntynyttä napostelua raportoi jopa kolmannes työikäisistä. Samankaltaisia havaintoja siitä, että kriisitilanteissa ruoankulutuksessa ja aterioinnissa tapahtuu muutoksia, on aiemmassa kirjallisuudessa. (7-13). Näiden syyksi on esitetty $\mathrm{mm}$. tunnetasolla tapahtuvia muutoksia $(7,9,14,15-18)$. 
Useissa tutkimuksissa on saatu viitteitä fyysisen aktiivisuuden vähenemisestä koronaepidemian aikana. (6-8, 14, 19-23). Myös yhdysvaltalaisen aktiivisuusrannekkeita ja älykelloja markkinoivan yrityksen Fitbitin aineisto osoittaa fyysisen aktiivisuuden vähentyneen maailmanlaajuisesti rajaamistoimien aikana. (24). Pitkittäistutkimuksissa on lisäksi havaittu, että fyysisesti aktiiviset ihmiset ovat vähentäneet epidemian aikana liikuntaa liikkumattomia ihmisiä enemmän. (14, 19). Tämän tutkimuksen perusteella työmatkaliikunta on vähentynyt etenkin ylimmässä koulutusryhmässä. Tätä selittänee etätyö, joka lisääntyi etenkin ylimmässä koulutusryhmässä. Alempiin sosioekonomisiin ryhmiin kuuluvia työskentelee enemmän aloilla, joilla etätyön tekeminen ei ole mahdollista (25) ja todennäköisesti siksi työmatkaliikunnassakaan ei nähdä samanlaista vähentymistä. Kiinnostavaa on, että osa ylimmässä koulutusryhmissä olevista raportoi lisänneensä vapaa-ajan liikuntaa ja saattaakin olla, että työmatkaliikunnan poisjäämistä on kompensoitu lisäämällä vapaa-ajan liikuntaa lisäämällä.

Tutkimustuloksia tarkasteltaessa on muistettava, että tässä tutkimuksessa ei arvioida tutkittavien elintapojen lähtötilannetta, eli esim. sitä, kuinka suuri osuus vastaajista eri koulutusryhmissä täytti liikunta- tai ravitsemussuositukset. Aiempien tutkimusten perusteella heikommassa sosioekonomisessa asemassa olevien terveystottumukset ovat monella tapaa huonommat kuin korkeammassa asemassa olevilla. (26-27). Lähtötilanteilla on terveyden kannalta keskeinen merkitys. Esimerkiksi paljon liikkuva voi vähentää liikkumistaan ja silti liikkua suositusten mukaan, jolloin liikuntamäärien vähentämisellä ei ole samanlaisia epäsuotuisia vaikutuksia terveyteen kuin jos jo ennestään vähän liikkuva vähentää entisestään liikuntaa.

Tutkimuksen perusteella ylimmässä koulutusryhmässä olevat raportoivat alimpaan verrattuna useammin sosiaalisen kanssakäymisen ja toiveikkuuden tulevaisuuden suhteen vähentyneet. Aiemmissa tutkimuksissa on havaittu, että koronaepidemiasta seuranneet rajaamistoimet ovat vaikuttaneet monen arkielämään aiheuttamalla ahdistusta, yksinäisyyden tunteen lisääntymistä ja läheisyyden tunteen vähenemistä (28). On viitteitä siitä, että perheen kanssa vietetyn ajan lisääntymisen seurauksena perheen sisäiset ristiriidat olisivat lisääntyneet epidemian aikana (29). Toisaalta, aikaisemman kirjallisuuden perusteella tiedetään, että yksinäisyys lisää merkittävästi psyykkistä ja fyysistä sairastavuutta sekä kokonaiskuolleisuutta (30).

Tämän tutkimuksen vahvuus on, että se perustuu kolmeen, suomalaista aikuisväestöä edustuvaan aineistoon, joissa on kerätty samankaltaisin menetelmin tietoa epidemian ja sen rajaamistoimien vaikutuksista elintapoihin ja arkielämään. Vaikka osallistumisaktiivisuus on kansainvälisesti tarkasteltuna ollut hyvää tasoa, on mahdollista, että katoon on valikoitunut enemmän ihmisiä, jotka ovat olleet haastavassa tilanteessa jo ennen epidemiaa tai ihmisiä, joita epidemia on erityisen raskaasti koetellut. Kadon valikoitumisen vaikutuksia tuloksiin on kuitenkin pyritty minimoimaan käyttämällä analyyseissä painokertoimia. Lisäksi on muistettava, että tässä tutkimuksessa tarkastellaan koettuja elintapa- ja arkielämän muutoksia, ja on mahdollista, että vastaajat ovat eri tavoin tunnistaneet ja raportoineet näitä muutoksia (esim. ylimpään koulutusryhmään kuuluvat ovat saattaneet muita herkemmin tunnistaa ja raportoida muutoksia). Vaikka aineistojen keruuajankohdat hieman eroavat, eivätkä käytetyt muuttujat ole täysin vertailukelpoisia, ovat tulokset keskenään linjassa, mikä vahvistaa luotettavien johtopäätösten tekemistä.

\section{JATKOTUTKIMUKSEN TARVE JA JOHTOPÄÄTÖKSET}

Tämä tutkimus perustuu tietoihin, jotka on kerätty koronaepidemian ensimmäisen ja toisen aallon aikana, aikavälillä huhtikuu 2020 ja maaliskuu 2021. Tätä tutkimusta tehtäessä Suomi elää siis vielä keskellä koronaepidemiaa ja on mahdotonta tarkkaan ennakoida, miten epidemia ja sen rajaamistoimet lopulta vaikuttavat väestöryhmittäisiin terveys- ja hyvinvointieroihin. Koronakriisin pitkän aikavälin vaikutukset väestöön riippuvat monien asioiden summasta mm. epidemian kestosta ja vaikutuksesta työllisyyteen. Huolestuttavaa on taloudellisen toimeentulon heikkeneminen alimpaan koulutusryhmään kuuluvilla sekä ylimpään koulutusryhmään kuuluvien kokemat kielteiset muutokset sosiaalisissa suhteissa. Tämä saattaa pidemmällä aikavälillä heijastua laajemmin ao. väestöryhmien elintapojen heikkenemisenä ja edelleen lisääntyneenä sairastuvuutena. Epidemiatilanteen pahentuessa tai pitkittyessä voidaan olettaa, että kielteiset vaikutukset terveyteen ja 
hyvinvointiin muuttuvat pysyvämmäksi tai jopa lisääntyvät. Mikäli aiemmin terveellisiä elintapoja noudattavan väestöryhmän elintavat muuttuvat epäterveellisempään suuntaan, kasvaa koko yhteiskunnan sairastavuustaakka entisestään. Ihmisten erilaisten tilanteiden tunnistaminen ja ymmärtäminen on tärkeää, jotta voidaan ennakoida koronaepidemian pitkäaikaisia vaikutuksia ja ehkäistä kielteisiä vaikutuksia.

Keskeistä jatkotarkasteluissa on huomioida myös se, että koronaepidemia on levinnyt maan eri osissa eri tavoin ja rajaamistoimien voimakkuus on niin ikään vaihdellut alueesta toiseen. Alustavien havaintojen perusteella elintapojen ja arkielämän muutokset ovat suurempia alueilla, joilla epidemia on ollut vakavin (31). Jatkotutkimuksissa tulisikin arvioida sitä, ovatko epidemian ja sen rajaamistoimien vaikutukset elintapoihin ja arkielämään eri koulutusryhmissä yhteyksissä epidemian vakavuuteen.

Tämän tutkimuksen tulokset vahvistavat käsitystä siitä, että koronakriisi on horjuttanut äkillisesti monen arkea. Elintavoissa ja arkielämässä tapahtuneet muutokset ovat moninaisia ja vaihtelevat myös koulutusryhmittäin. Terveyden ja hyvinvoinnin kannalta epäsuotuisat muutokset arkielämässä ja elintavoissa, etenkin kasaantuessaan samalle henkilölle, saattavat pitkällä ai- kavälillä heijastua lisääntyneenä sairastavuutena ja kansanterveyden yleisenä heikkenemisenä. On myös mahdollista, että epidemia entisestään kärjistää sosioekonomisia terveys- ja hyvinvointieroja, erityisesti jos koulutusryhmien tuloerot ja erot työolosuhteissa kasvavat. Jotta mahdolliset terveyden ja hyvinvoinnin kannalta epäsuotuisat kehityskulut voidaan havaita ajoissa ja tunnistaa ne väestöryhmät, joissa riski epäsuotuisalle kehitykselle on erityisen suuri, ajankohtainen, luotettavaa tieto epidemian heijastevaikutuksista on välttämätöntä. Erityisesti tulee jatkossa myös tunnistaa tekijöitä, jotka altistavat terveyden kannalta negatiivisiin muutoksiin.

\section{RAHOITTAJAT:}

Valtion lisätalousarviossa Covid 19 -tutkimukseen osoitettu THL:n koordinoima rahoitus.

\section{KIRJOITTAJIEN KONTRIBUUTIOT:}

Haario oli vastuussa käsikirjoituksen kirjoittamisesta. Koponen, Parikka, Martelin, Koskinen ja Lundqvist osallistuivat tutkimusaineistojen suunnitteluun ja keräämiseen. Härkänen osallistui tilastollisten analyysien suunnitteluun ja toteutukseen. Kaikki kirjoittajat osallistuivat tutkimuksen suunnitteluun, tulosten tulkintaan ja käsikirjoituksen kommentointiin.

\section{Haario, P., Koponen, P., Parikka, S., Härkänen, T., Martelin, T., Koskinen, S., Lundqvist, A. The impact of the corona epidemic and its restrictive measures on health behaviours and everyday life by educational groups. Sosiaalilääketieteellinen aikakauslehti - Journal of Social Medicine 202 I : 58: 209-2 19.}

Restrictions during corona epidemic have influenced public health and welfare in many different ways. Many adverse health effects have been estimated to accumulate in lower socioeconomic population groups. However, the research data on this subject is scarce. The aim of this study is to examine the effects of corona epidemic on health behaviours and everyday lifetime in different educational groups.

This study is based on responses from randomly selected individuals between the ages of 30-69 in three population surveys representing the adult population: The Serological population study of the corona epidemic $(n=3772)$, the National FinSote 2020 survey $(n=10847)$ and the FinHealth 2017 follow-up study $(n=3696)$ implemented by the Finnish institute for health and welfare (THL). The survey data for all surveys was collected between April 2020 and March 2021.

The results of these population studies show that the epidemic and measures aiming to control it have brought about various changes in health behaviours and everyday life. But especially when it comes to health behavior, the impact is similar in different educational groups. Physical activity when commuting declined especially among the members of the higher educational group, which is most likely related to the marked increase in remote working. Those belonging to the higher educational group also reported more often negative changes in social relations compared to those in lower educational groups. On the other hand, the highly educated group suffered 
less financially compared to those with a lower education.

Unfavorable changes in health behaviours and everyday life in terms of health and welfare may in the long run reflect on increased morbidity and a general decline of public health. It is also possible that the corona epidemic will further exacerbate socio-economic disparities in health and welfare if income disparities increase and changes in working life are divergent across population groups. In order for the unfavorable development patterns in health and welfare to be identified and to identify the population at risk, current and reliable information about the effects of the epidemic is essential.

Keywords: Corona epidemic, socioeconomic status, health differences, educational groups.

\author{
Saapunut (11.03.2021) \\ Hyväksytty (14.07.2021)
}

\section{LÄHTEET}

(1) Ahmed F, Ahmed N, Pissarides C, ym. Why inequality could spread COVID-19. Lancet Public Health 2020;5(5):e240. doi: 10.1016/S2468-2667(20)30085-2

(2) Burström B, Tao W. Social determinants of health and inequalities in COVID-19. Eur J Public Health 2020;30(4):617-618. doi: 10.1093/eurpub/ckaa095

(3) Lehtonen R, Pahkinen E. Practical Methods for Design and Analysis of Complex Surveys. 2nd ed. Wiley; 2004.

(4) Härkänen T, Kaikkonen R, Virtala E, ym. Inverse probability weighting and doubly robust methods in correcting the effects of non-response in the reimbursed medication and self-reported turnout estimates in the ATH survey. BMC Public Health 2014;14(1):1-10. doi: 10.1186/1471-2458-14-1150

(5) Härkänen T, Karvanen J, Tolonen H, $\mathrm{ym}$. Systematic handling of missing data in complex study designs-experiences from the Health 2000 and 2011 Surveys. J Appl Stat 2016;43(15):2772-2790. doi: $10.1080 / 02664763.2016 .1144725$

(6) Terveyden ja hyvinvoinnin laitos. Koronaepidemian vaikutukset hyvinvointiin, palveluihin ja talouteen. THL:n seurantaraportti, viikot 2-3/2021, 27.1.2021. Luettu 25.1.2021. http://urn.fi/URN:NBN:fi-fe202101121563

(7) Ammar A, Brach M, Trabelsi K, ym. Effects of COVID-19 Home Confinement on Eating Behaviour and Physical Activity: Results of the ECLB-COVID19 International Online Survey. Nutrients 2020;12(6):1583. doi: 10.3390/nu12061583

(8) Giacalone D, Frøst MB, Rodríguez-Pérez C, ym. Reported Changes in Dietary Habits During the COVID-19 Lickdown in the Danish Population: The Danish COVIDiet Study. Front Nutr 2020;7:592112. doi: 10.3389/fnut.2020.592112

(9) Kriaucioniene V, Bagdonaviciene L, RodríguezPérez C, ym. Associations between Changes in Health Behaviours and Body Weight during

the COVID-19 Quarantine in Lithuania: The Lithuanian COVIDiet Study. Nutrients 2020;12(10):3119. doi: 10.3390/nu12103119

(10) Ismail LC, Osaili TM, Mohamed MN, ym. Eating Habits and Lifestyle during COVID-19 Lockdown in the United Arab Emirates: A Crosssectional Study. Nutrients 2020;12(11):3314. doi: 10.3390/nu12113314

(11) Blaszczyk-Bębenek E, Jagielski P, Boleslawska I, ym. Nutrition Behaviors in Polish Adults before and during COVID-19 Lockdown. Nutrients 2020;12(10):3084. doi: 10.3390/nu12103084

(12) Sánchez-Sánchez E, Ramirez-Vargas G, Avellaneda-López Y, ym. Eating Habits and Physical Activity of the Spanish Population during the Covid-19 Pandemic Period. Nutrients 2020;12(9):2826. doi: 10.3390/nu12092826

(13) Chenarides L, Grebitus C, Lusk JL, ym. Food consumption behavior during the COVID-19 pandemic. Agribusiness 2020. Online ahead of print. doi: 10.1002/agr.21679

(14) Martinez-de-Quel Ó, Suárez-Iglesias D, López-Flores M, ym. Physical activity, dietary habits and sleep quality before and during COVID-19 lockdown: A longitudinal study. Appetite 2020;158:105019. doi: 10.1016/j.appet.2020.105019

(15) Cancello R, Soranna D, Zambra G, ym. Determinants of the Lifestyle Changes during COVID-19 Pandemic in the Residents of Northern Italy. Int J Environ Res Public Health 2020;28:17(17):6287. doi: 10.3390/ijerph17176287

(16) Górnicka M, Drywien ME, Zielinska MA, ym. Dietary and Lifestyle Changes During COVID-19 and the Subsequent Lockdowns among Polish Adults: A CrossSectional Online Survey PLifeCOVID-19 Study. Nutrients 2020;12(8):2324. doi: 10.3390/nu12082324

(17) Marty L, De Lauzon-Guillain B, Labesse M, $\mathrm{ym}$. Food choice motives and the nutritional quality of diet during the COVID-19 lockdown 
in France. Appetite 2021;157:105005. doi: 10.1016/j.appet.2020.105005

(18) Mattioli AV, Sciomer S, Cocchi C, ym. Quarantine during COVID-19 outbreak: Changes in diet and physical activity increase the risk of cardiovascular disease. Nutr Metab Cardiovasc Dis 2020;30(9):1409-1417. doi: 10.1016/j.numecd.2020.05.020

(19) Castañeda-Babarro A, Arbillaga-Etxarri A, Gutiérrez-Santamaría B, ym. Physical Activity Change during COVID-19 Confinement. Int J Environ Res Public Health 2020;17(18):6878. doi: 10.3390/ijerph17186878

(20) Flanagen EW, Beyel RA, Fearnbach SN, ym. The Impact of COVID-19 StayAt-Home Orders on Health Behaviors in Adults. Obesity 2021;29(2):438-445. doi: 10.1002/oby.23066

(21) Knell G, Robertson MC, Dooley EE, ym. Health Behavior Changes During COVID-19 Pandemic and Subsequent "Stay-at-Home" Orders. Int J of Environ Res Public Health 2020;28:17(17):6268. doi: 10.3390/ijerph17176268

(22) Stanton R, To QG, Khalesi S, ym. Depression, Anxiety and Stress during COVID-19: Associations with Changes in Physical Activity, Sleep, Tobacco and Alcohol Use in Australian Adults. Int J Environ Res Public Health 2020;17(11):4065. doi: 10.3390/ijerph17114065

(23) Zaworski K, Kubińska Z, Dziewulska A, ym. Physical activity of Poles in the care for their health potential before and during the COVID-19 pandemic. Disaster Med Public Health Prep 2020;22:1-13. doi: $10.1017 / \mathrm{dmp} .2020 .398$

(24) Fitbit, Inc. The Impact of Coronavirus on Global Activity. Luettu 18.1.2021. Available online: https://blog.fitbit.com/covid-19- global-activity/ (accessed on 15 May 2020).

(25) Tilannehuoneen raportti: Koronavirus ja terveyserot - Missä sosioekonomisissa ryhmissä koronatartuntoja on Suomessa havaittu eniten? Helsinki Graduate School of Economics. Luettu 24.2.2021. https://www.helsinkigse.fi/corona/ tilannehuoneen-raportti-koronavirus-jaterveyserot-missa-sosioekonomisissa-ryhmissakoronatartuntoja-on-suomessa-havaittu-eniten/

(26) Palosuo H, Koskinen S, Lahelma, ym. Terveyden eriarvoisuus Suomessa. Sosioekonomisten terveyserojen muutokset 1980-2005. Luettu 5.3.2021. https://julkaisut.valtioneuvosto. fi/bitstream/handle/10024/70638/ URN\%3aNBN\%3afi-fe201504226300. pdf? sequence $=1 \&$ is Allowed $=$

(27) Lahelma E, Pentala O, Helldan A, ym. Koetun terveyden koulutusryhmittäiset erot ovat pysyneet tasaisen suurina. Lääkärilehti 2017;72:1629-1634.

(28) Tull MT, Edmonds KA, Scamaldo KM, ym. Psychological Outcomes Associated with Stay-at-Home Orders and the Perceived Impact of COVID-19 on Daily Life. Psychiatry Res 2020;289:113098. doi: 10.1016/j.psychres.2020.113098

(29) Zvolensky MJ, Garey L, Rogers AH, ym. Psychological, addictive, and health behavior implications of the COVID-19 pandemic. Behav Res Ther 2020;134:103715. doi: 10.1016/j.brat.2020.103715

(30) Leigh-Hunt N, Bagguley D, Bash K, ym. An overview of systematic reviews on the public health consequences of social isolation and loneliness. Public Health 2017;152:157-171. doi: 10.1016/j.puhe.2017.07.035

(31) Parikka S, Ikonen J, Koskela T, ym. Koronan vaikutukset vaihtelevat alueittain - eroja myös ikääntyneillä sekä toimintarajoitteisilla verrattuna muuhun väestöön. Kansallisen FinSote-tutkimuksen ennakkotuloksia syksyllä 2020. Verkkojulkaisu: thl.fi/finsote

\section{Peppi HaArio}

FT, tutkija

Terveyden ja hyvinvoinnin laitos

\section{PÄIVIKKI KOPONEN}

$T t T$, dosentti, johtava asiantuntija

Terveyden ja hyvinvoinnin laitos

\section{Suvi PARIKKA}

VTM, kehittämispäällikkö

Terveyden ja hyvinvoinnin laitos

\section{TOMMI HäRKÄNEN}

FT, dosentti, tutkimuspäällikkö

Terveyden ja hyvinvoinnin laitos

Tuija Martelin

VTT, tutkimuspäällikkö

Terveyden ja hyvinvoinnin laitos

Seppo Koskinen

LT, tutkimusprofessori

Terveyden ja hyvinvoinnin laitos

ANNAMARI LundQVist

FT, dosentti, johtava tutkija

Terveyden ja hyvinvoinnin laitos 